\title{
ESTIMATION OF S-WAVE VELOCITY STRUCTURES IN YOGYAKARTA BASIN, INDONESIA
}

\author{
Tun Naing ${ }^{* 1}$, Subagyo Pramumijoyo ${ }^{1}$, and Hiroshi Kawase ${ }^{2}$ \\ ${ }^{1}$ Department of Geological Engineering, Gadjah Mada University, Yogyakarta, Indonesia \\ ${ }^{2}$ Department of Architecture and Urban Design, Faculty of Human-Environment Studies, Kyushu University
}

\begin{abstract}
For the theoretical simulation or prediction of strong ground motion, it is prime importance to get information of underground structures, especially for sedimentary layers overlying on bedrock, like in Yogyakarta Basin. The Standard Penetration Test, Spectral Analysis of Surface Wave (SASW) and other geotechnical properties are used to estimate $S-$ wave velocity structures in this basin. SPT tests were conducted at nine sites and SASW measurements were performed at seventeen sites. As a result, the S-wave velocity structures of top $30 \mathrm{~m}$ depth had been evaluated in each site. The average shear wave velocity $v_{s}^{30}$ had been successful estimated and the sites are classified into three types; soft soil, medium dense soil and hard soil. All sites where SPT performed are on soft soil according to their $v_{s}^{30}$. However, according to $v_{s}^{30}$ from SASW measurements, 10 sites are located on medium dense soils type, 5 sites on dense soils and 2 sites on soft soils. The acceptable equivalent $S$-wave velocitystructure is observed by comparing the results from SASW and geotechnical approach in Imogiri, Bambang Lipuro, Pundong (Watu, Pranti) and Pandak (Wijirejo) areas.
\end{abstract}

Keywords: Ground motion, underground structure, sedimentary layer, SPT, SASW, Pundong.

${ }^{*}$ Corresponding author: T. NAING, Department of Geological Engineering, Faculty of Engineering, Gadjah Mada University, Jl. Grafika 2 Yogyakarta, 55281, Indonesia

\section{Introduction}

The May 27, 2006 earthquake caused severe damage in Yogyakarta Basin, especially in Bantul area. One main reason for such damage is strong ground motion and ground amplification. It is also important to determine site effects quantitatively. During an earthquake, the subsurface soil column acts like a filter with strain-dependent properties that can increase the duration and amplitude of shaking in a narrow frequency band related to the soil thickness, physical properties ( $\mathrm{P}$ - and S-wave velocities, density), and the shape of the surface and subsurface boundaries. The spectral content (amplitude, period, and phase) and duration of earthquake recordings can therefore be significantly affected by local site conditions, especially at unconsolidated soil and sediment sites with a near-surface impedance contrast with underlying bedrock. The resonant period of the ground is therefore of great importance for earthquake engineering (Molnar et al., 2007).

The most influential parameter in determining strong ground motion is the subsurface shear-wave velocity $\left(V_{s}\right)$ structure. The 2005 Canadian National Building Code is based on averaging the shear-wave velocity of the top 30 $\mathrm{m}$ (or equivalent) in order to designate a $\mathrm{Na}$ tional Earthquake Hazard Reduction Program (NEHRP) amplification site class with an appropriate multiplicative amplification hazard factor. This is similar to current practice in the 
United States, and now in Europe (Eurocode 8), (Molnar et al., 2007).

The theoretical evaluation of strong motions and site effects requires information on shear wave velocity structures, especially for sedimentary layers above the bedrock. Theoretical simulation of strong motions for 1995 Kobe earthquake had shown that sites effects caused by 3D basin structure have an important role in strong motions (Kawase and Matsushima, 1998). For 2006 Yogyakarta earthquake, there is no enough information on velocity structures of the basin. Therefore, the shear wave velocity structures in Yogyakarta Basin is estimated by using Standard Penetration Tests at nine boreholes and Spectral Analysis of Surface Wave (SASW) measurements in seventeen places as first stage. The depths of SASW measurements and SPT test are generally greater than $30 \mathrm{~m}$. Therefore, the sites in this basin are classified based on average shear wave velocity, $v_{s}^{30}$.

\section{SASW Method}

The SASW method is a relatively new in-situ seismic method for determining shear wave velocity profiles. Measurement is performed on the ground surface, and so, the cost of measurements is less than with traditional borehole methods. The basis of the SASW method is the dispersive characteristic of Rayleigh waves when traveling through a layered medium. Rayleigh wave velocity is determined by the material properties (primarily shear wave velocity, but also compression wave velocity and material density) of the subsurface.

In Yogyakarta Basin, the SASW measurements are performed in seventeen areas throughout the basin as shown in Figure 1. All measurements reached to the depth of 30 $\mathrm{m}$ and above. Therefore, the obtained data can reflect the effects of loose to dense sediments in this basin and applicable for seismic response analysis and strong ground motion.

General Procedure SASW testing consists of measuring the surface wave dispersion curve at the site and interpreting it to obtain the corresponding shear wave velocity profile. A dy-

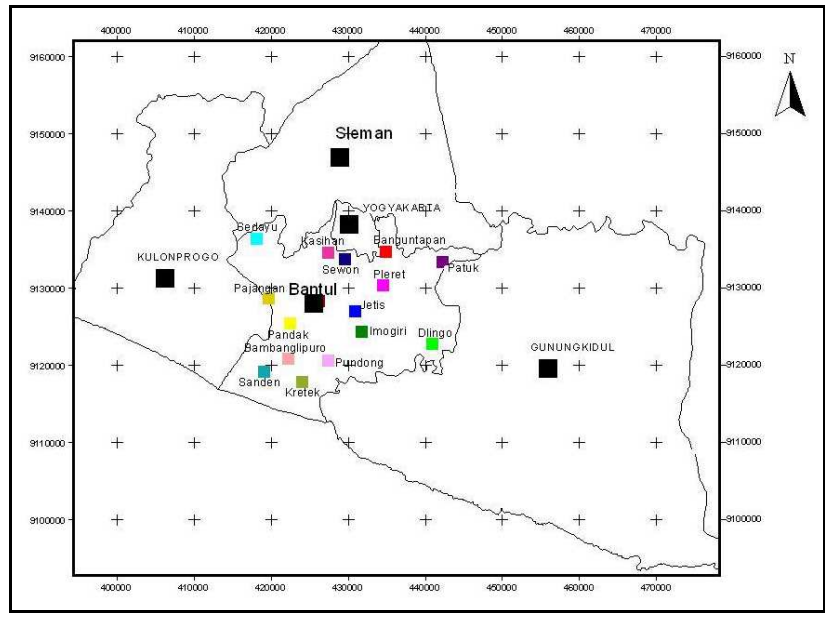

Figure 1: Locations of SASW measurements

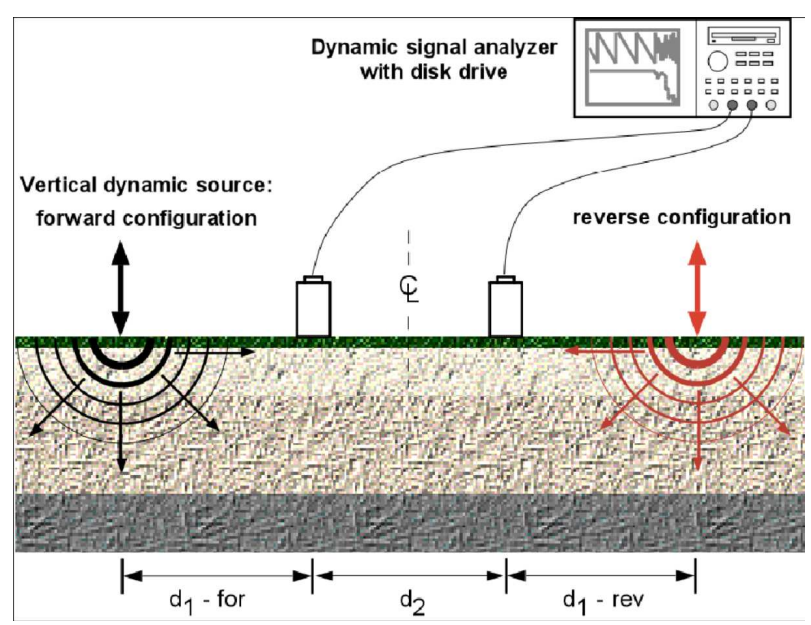

Figure 2: Diagram of SASW measurement

namic source is used to generate surface waves of different wavelengths (or frequencies) which are monitored by two or more receivers at known offsets as shown in Figure 2. Data from forward and reverse profiles are averaged together. An expanding receiver spread is used to avoid near field effects associated with Rayleigh waves and the source receiver geometry is optimized to minimize body wave signal. During data analysis, all phase data are manually checked through an interactive masking process to discard low quality data.

Data Analysis First of all, the recorded data are transformed into cross power spectrum by using fast Fourier Transform method. The obtained auto power spectrum is then trans- 
formed again into phase velocity spectrum which reflects the dispersive characteristics of Rayleigh waves. By using selected inversion processes, the shear wave velocity structures of studied areas have been obtained.

$$
\begin{gathered}
\text { Recorded data } \\
\Downarrow \\
\text { Fast Fourier Transform } \\
Y_{1}(\omega)=F F T\left(y_{1}(t)\right), Y_{2}(\omega)=F F T\left(y_{2}(t)\right) \\
\Downarrow \\
\text { Cross Power Spectrum } \\
G_{y_{1} y_{2}}=Y_{1}(\omega) \cdot Y_{2}(\omega) \\
\Downarrow \\
\text { Time Delay } \\
t(\omega)=\text { phase }\left(G G_{y_{1} y_{2}}(f)\right) / \omega \\
\Downarrow \\
\text { Phase Velocity } \\
V_{R}(\omega)=X / t(\omega) \\
\Downarrow \\
\text { Inversion Process } \\
\Downarrow
\end{gathered}
$$

Shear Wave Velocity Structure with Depth

\section{Geotechnical approach}

\section{Standard Penetration Test (SPT)}

The standard penetration tests were performed at nine areas in Yogyakarta Basin, together with drilling program. The borehole locations in which SPT tests had been carried out were shown in Figure 3. The SPT test was conducted at every $2 \mathrm{~m}$ interval in bore holes. Then, the average $\mathrm{N}$-vales are determined for each layer of evaluated subsurface soil profile in nine areas by using the following equation.

$$
\bar{N}=\frac{\sum_{i=1}^{n} t_{i}}{\sum_{i=1}^{n} t_{i} / N_{i}}
$$

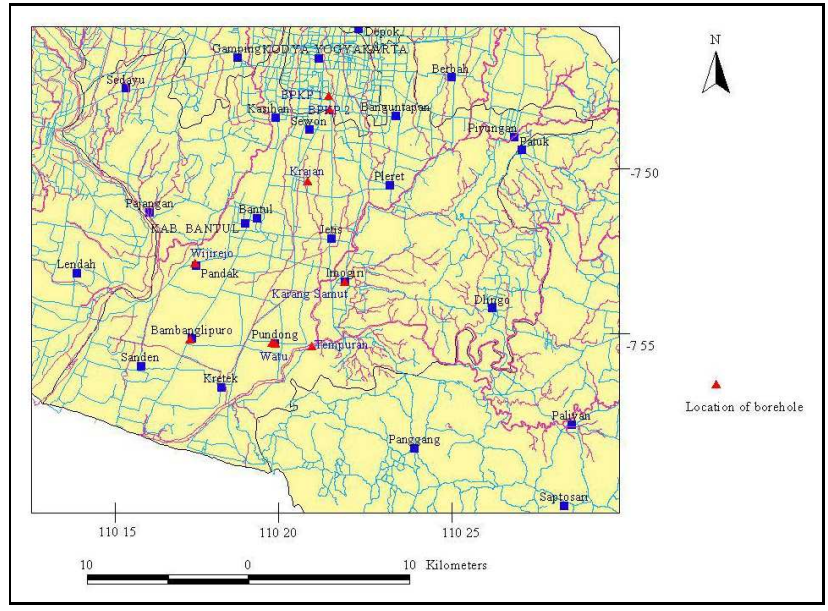

Figure 3: Location of Boreholes where SPT were performed in Yogyakarta Basin

Where,

$t_{i}=$ thickness of ith soil layer

$N_{i}=$ recorded blows number of ith soil layer

$n=$ number of soil layer

\section{Data Analysis}

By using corrected average $\mathrm{N}$-values, void ratio, specific gravity and shear strength parameters, the shear wave velocities structures have been estimated step by step method. First of all, the effective unit weight for each layer was determined as follows (Craig, 1991).

$$
\gamma_{e f f}=\frac{G_{s} \gamma_{w}}{1+e}(\text { Above water table })
$$

$$
\gamma_{e f f}=\left(\frac{G_{s}-1}{1+e}\right) \gamma_{w}(\text { Under water table })
$$

Where,

$\gamma_{e f f}=$ effective unit weight of each layer

$G_{S}=$ specific gravity of each layer

$\gamma_{w}=$ unit weight of water

$e=$ void ratio of each layer

The effective vertical pressure, effective confining pressures for each layer were determined as follows.

$$
\begin{gathered}
\bar{\sigma}_{v}=\gamma_{e f f} \times d e p t h \\
\bar{\sigma}_{0}=1 / 3\left(\bar{\sigma}_{v}+\bar{\sigma}_{2}+\bar{\sigma}_{3}\right)
\end{gathered}
$$




$$
\bar{\sigma}_{2}=\bar{\sigma}_{3}=K_{0} \bar{\sigma}_{v}
$$

Where, $K_{0}$ is the coefficient of earth pressure at rest

$$
\begin{aligned}
& K_{0}=1-\sin \phi \text { (For sands) } \\
& K_{0}=0.4+0.007(P I) \text { (For } 0 \leq P I \leq 40 \% \text { ) }
\end{aligned}
$$

(For normally consolidated clays)

$\bar{\sigma}_{v}=$ effective vertical pressure

$\bar{\sigma}_{0}=$ effective confining pressure

Based on determined effective vertical pressure, corrected $N_{60}$ values and the shear modulus of each soil layer were estimated by using the following relation (Seed et al., 1986).

$$
G_{\text {max }} \approx 35 \times 1000 N_{60}^{0.34}\left(\bar{\sigma}_{v}\right)^{0.4}
$$

Where,

$G_{\max }=$ maximum shear modulus of each layer

$N_{60}=N$-value of $60 \%$ free-fall energy

Finally, the shear wave velocity structures of the studied areas had been determined based on obtained shear modulus values, void ratio and confining pressure of each layer, by using the following relations (Das, 1993).

$$
\begin{gathered}
v_{s}=\sqrt{\frac{G_{\max }}{\rho}} \\
v_{s}=(18.43-6.2 e)\left(\bar{\sigma}_{0}\right)^{1 / 4}
\end{gathered}
$$

Where,

$$
\begin{aligned}
& v_{S}=\text { shear wave velocity of soil layer } \\
& \rho=\text { density of soil layer }\left(\frac{\gamma_{e f f}}{g}\right)
\end{aligned}
$$

\section{Results}

The phase velocities of dispersive Rayleigh waves in Bambang Lipuro, Banguntapan, Kasihan, Piyungan, Sedayu, and Bantul areas show little or no variation in dispersion of Rayleigh waves as shown in Figure 4(a-f). The gradual increase in shear wave velocities with depths has been observed in these areas and the Swave velocity structures of these areas are shown in Figure 4(a-f).

Some changes and variations of dispersive characteristics have been observed in phase velocity spectra of Sanden, Imogiri, Pajangan and Dlinggo areas as shown in Figure 5(a-d). The variations in dispersive characteristics of Rayleigh reflect the complex changes in underlying subsurface layers. There are also changes in shear wave velocity structures and which can be seen in Figure 5(a-d).

In Jetis, Pleret and Srandakan areas, similar phase velocity spectra are observed with some variations and are shown in Figure 6(ac). There are small changes in shear wave velocity structures as shown in Figure $6(\mathrm{a}-\mathrm{c})$. The dispersion of Rayleigh wave in Kretek and Pundong areas is quite different from other areas. The phase velocity spectra and shear wave velocity of these areas are shown in Figure $7(a, b)$. The resulted shear wave velocity structures from geotechnical evaluation are described in Table 1-9.

\section{Discussion}

In this study, Spectral Analysis of Surface Wave (SASW) method used as a tool to evaluate the shear wave velocity structures of Yogyakarta Basin and standard penetration test and other geotechnical aspects are also applied to support SASW measurements.

The shear wave velocity structures in Bambang Lipuro, Banguntapan, Kasihan, Piyungan, Sedayu, and Bantul area, gradually increase generally starting from $154 \mathrm{~ms}^{-1}$ to greater than $800 \mathrm{~ms}^{-1}$. The shear wave velocity of Bambang Lipuro area is very low and that reflects the sediments in this area are loose and unconsolidated. Based on shear wave velocity atructures, Bantul and Piyungan areas are mainly composed of hard and consolidated sediments. But, the S-wave velocity in upper $6 \mathrm{~m}$ of Bantul area is low $\left(190 \mathrm{~ms}^{-1}\right)$ and is mainly dominated by loose and soft sediments. The medium dense sediments are dominant in Kasihan, Banguntapan and Sedayu area.

The phase velocities in Sanden, Imogiri, Pajangan and Dlinggo areas show the variation in dispersion characteristics of Rayleigh wave and also show distinct changes in S-wave velocity structures. Sudden changes indicate that there is a clear difference of the material properties in underlying layers. In Sanden and Pa- 
jangan area, highest S-wave velocity layer (> $500 \mathrm{~ms}^{-1}$ ) is found between $10 \mathrm{~m}$ and $15 \mathrm{~m}$ and gradually decreased and decreased after $15 \mathrm{~m}$. Soft layer is found in upper $6 \mathrm{~m}$. In Imogiri, high S-wave velocity layer is observed between $5 \mathrm{~m}$ and $10 \mathrm{~m}$ and then velocity is sharply decreased after $10 \mathrm{~m}$. The high velocity layers will be sandstone layers and low velocity layers will be clayey layers and silty sand layers. The complex nature of ground response will be observed in these areas during an earthquake.

There are no sharp changes in S-wave velocity structure of Jetis, Pleret and Srandakan areas. The low velocity layer $\left(180-190 \mathrm{~ms}^{-1}\right)$ is encountered only in uppermost $5 \mathrm{~m}$. After that, the velocity becomes constant up to $35 \mathrm{~m}$ depth at $250 \mathrm{~ms}^{-1}$. No hard layer is observed in these areas and in which only medium dense sediments are dominant. According to the S-wave velocity structures, Kretek and Pundong areas possess relatively hard layers in upper most 5 $\mathrm{m}$ and weaker sediments underlain up to $32 \mathrm{~m}$ depth.

\section{Comparison of Results}

By comparing the results from SASW and geotechnical approach in Imogiri, Bambang Lipuro, Pundong (Watu, Pranti) and Pandak (Wijirejo) areas, the acceptable equivalent swave velocity is observed. The maximum S-wave velocity in Bambang Lipuro is 177 of $\mathrm{ms}^{-1}$ from SASW and $187 \mathrm{~ms}^{-1}$ from SPT. The velocity from SASW was $156 \mathrm{~ms}^{-1}$, and 154.46 $\mathrm{ms}^{-1}$ from SPT in Watu, Pundong area and 156 $\mathrm{ms}^{-1}$ from SASW and $157 \mathrm{~ms}^{-1}$ from SPT in Pranti, Pundong area. However, some differences are also observed in Imogiri and Pandak, Wijirejo areas.

\section{Site Classification}

The site classification is provided according to SNI-1726-2002, in which soil condition is classified into three types: (1) soft soil, (2) medium dense soil, and (3) hard or dense soil based on average s-wave velocity $\left(v_{s}^{30}\right)$ of soils in top 30 $m$ depth. For that purpose, $\left(v_{s}^{30}\right)$ is determined by using the following equation (Fathani, 2007).

$$
v_{s}^{30}=\frac{\sum_{i=1}^{n} t_{i}}{\sum_{i=1}^{n} t_{i} / v_{s i}}
$$

The site classification based on $v_{s}^{30}$ calculated from SASW measurement is shown in Table 10 and that of from SPT is shown in Table 11.

\section{Conclusion}

The objective of this study is to estimate the S-wave velocity structure of Yogyakarta Basin, especially in southern part of basin, which is required for strong-motion evaluation for the 2006 Yogyakarta Earthquake and seismic response analysis for the future safety. To achieve this goal, SASW measurements in seventeen sites and geotechnical evaluation at nine sites were conducted. As a result, the S-wave velocity structures of top $30 \mathrm{~m}$ depth had been evaluated in each site. The average shear wave velocity $v_{S}^{30}$ had been successful estimated and the sites are classified into three types; soft soil, medium dense soil and hard soil. All sites where SPT performed are on soft soil according to their $v_{s}^{30}$. However, according to $v_{s}^{30}$ from SASW measurements, 10 sites are located on medium dense soils type, 5 sites on dense soils and 2 sites on soft soils.

Both tests were carried out in Imogiri, Bambang Lipuro, Pundong (Watu, Pranti) and Pandak (Wijirejo) areas and the maximum S-wave velocity structures are equivalent although there are some differences. Therefore, SASW measurements supported by geotechnical approach can be applied in seismic response analysis as a tool for evaluation of S-wave velocity structures.

However, all S-wave velocity structures evaluated in this study are shallow structures and deep S-wave velocity structures are needed to evaluate 3D basin structure which has a great effect on detail seismic response analysis and determination of strong ground motion.

In order to interpolate 3D basin structure spatially, both deep and shallow S-wave velocity structures are required and microtremor array measurement using array record of long-period 
and short-period is the best solution for that purpose.

\section{Acknowledgement}

Sincere gratitude is directed to Geological Engineering Department, UGM and Japan International Co-operation Agency (JICA) for their supports in every academic affair. The great debt of gratitude is to my advisor Dr. Subagyo Pramumijoyo for his guidance and suggestions. The acknowledgement is extended to Professor Dr. Hiroshi Kawase for his empowerment and advices. Special gratitude and appreciation are to Dr. Gunawan Handayani for his kind permission to use SASW data.

\section{References}

Craig R. F., 1991, Soil Mechanics, CHAPMAN \& HALL, 2-6 Boundary Row, London SE1 8HN.
Das B. M., 1993, Principles of Soil Dynamics, PWS-KENT Publishing Company, Boston, Massachusetts.

Fathani T. F., 2007, The Determination of Peak Ground Acceleration at Opak-Oyo Fault, Bantul Regency, Yogyakarta, The Yogyakarta Earthquake 2006, Geological Engineering Department, UGM.

Kramer, S.L., 1996, Geotechnical Earthquake Engineering, Prentice Hall, New Jersey.

Molnar S. et al., 2007, Comparison of Geophysical Shear Wave Velocity Methods, Ninth Canadian Conference, Ottawa, Canada

Panah A. K. et al., 2002, Site Effect Classification in East-Central of Iran, JSEE: Spring, Vol.4.No. 1/37.

Satoh T. et al., 2001, Estimation of S-Wave Velocity Structure in and around the Sendai Basin, Japan, Using Array Records of Microtremors, Bulletin of the seismological Society of America, 91, 2, pp. 206-218.

Satoh T. et al., 2001, S-Wave Velocity Structure of the Taichung Basin, Taiwan, Estimated from Array and single station Records of Microtremors, Bulletin of the seismological Society of America, 91,5 , pp. $1267-1282$. 


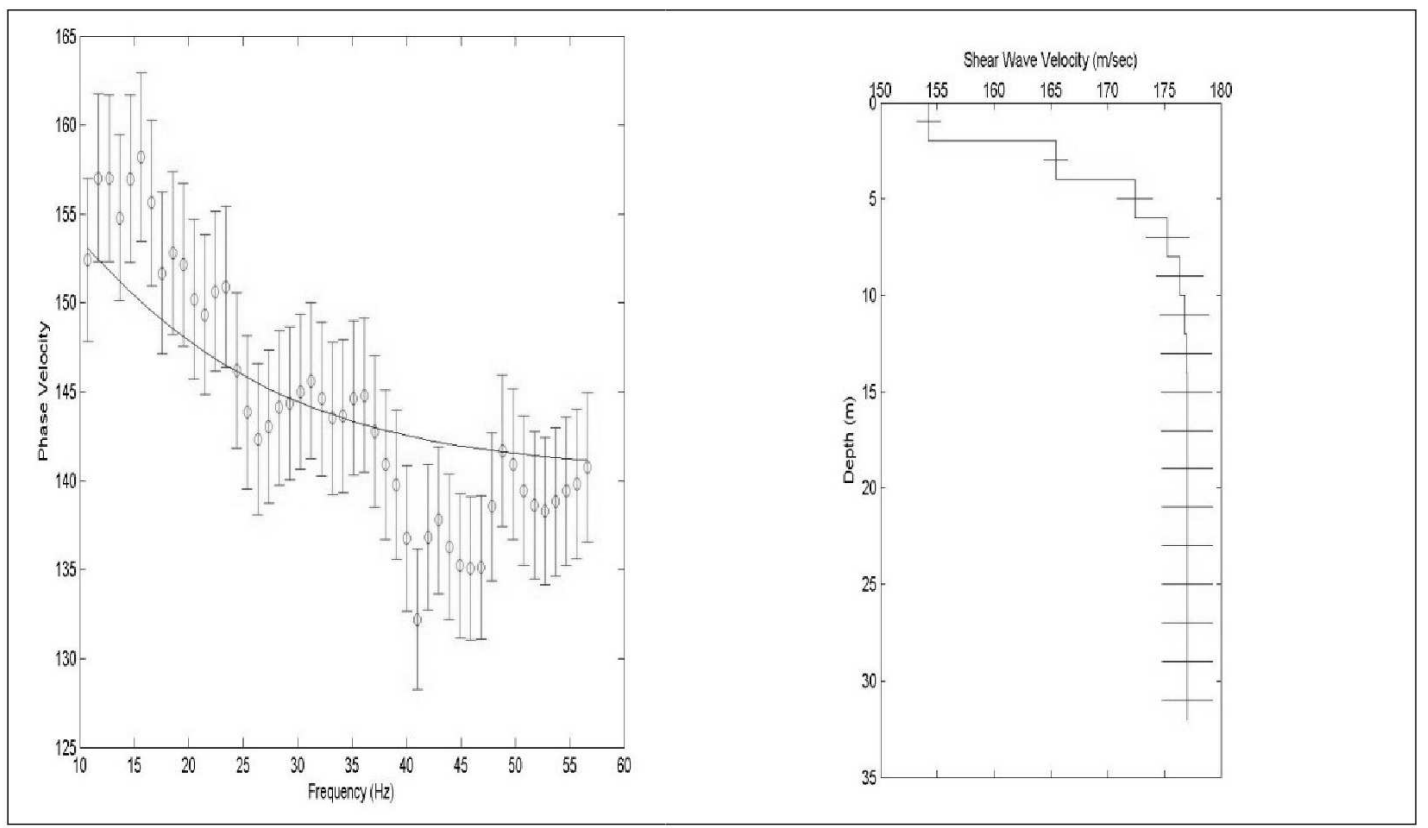

(a)

(b)

Figure 4a: (a) Phase Velocity (b) S-Wave velocity structure of Bambang Lipuro area

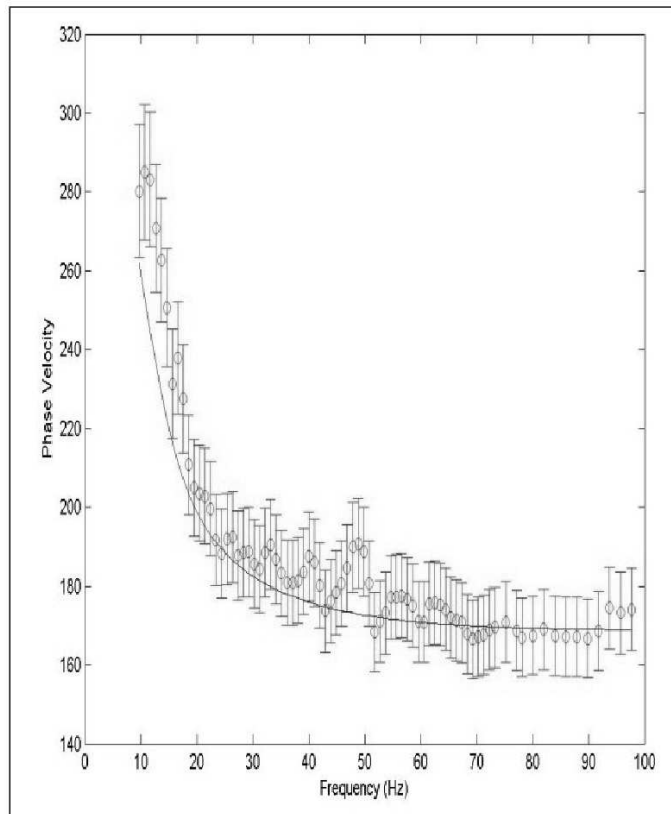

(a)

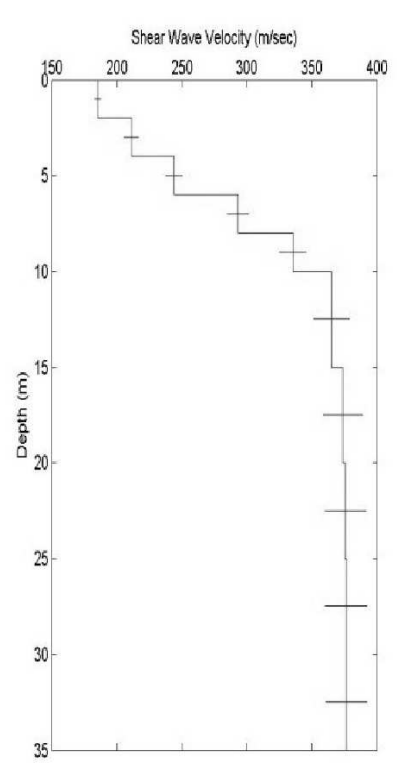

(b)

Figure 4b: (a) Phase Velocity (b) S-Wave velocity structure of Banguntapan area 


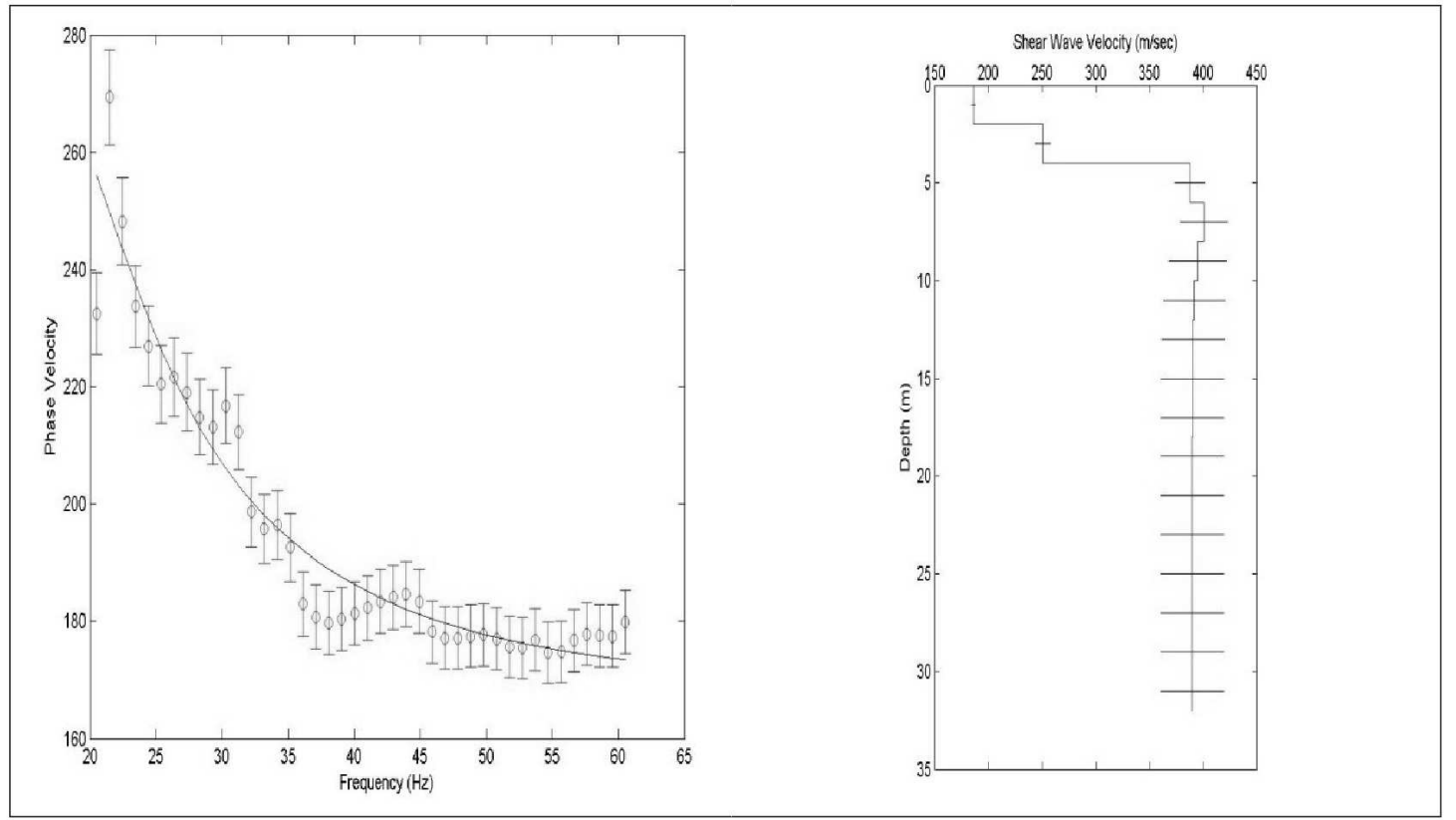

(a)

(b)

Figure 4c: (a) Phase Velocity (b) S-Wave velocity structure of Kasihan area

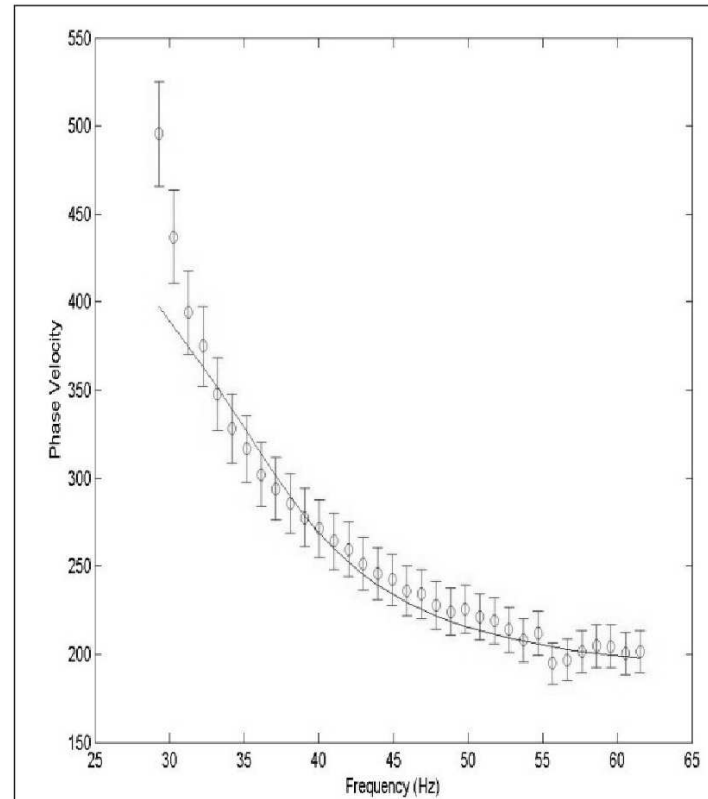

(a)

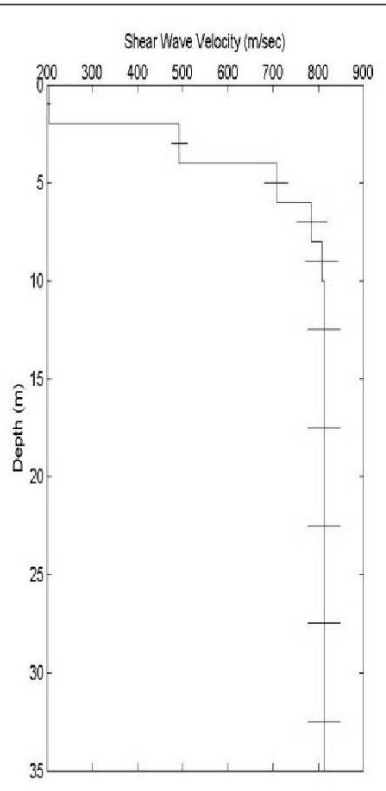

(b)

Figure 4d: (a) Phase Velocity (b) S-Wave velocity structure of Piyungan area 


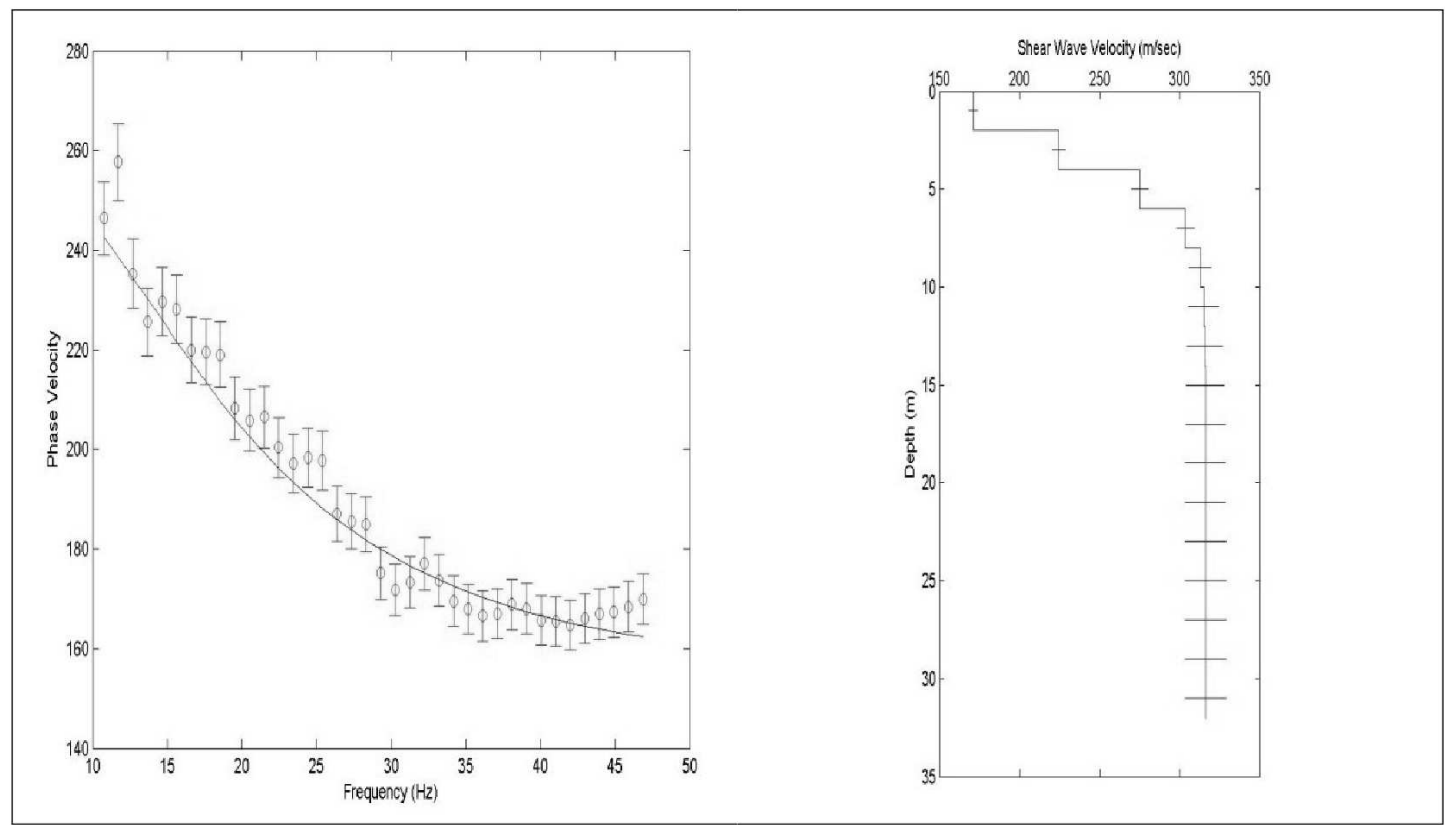

(a)

(b)

Figure 4e: (a) Phase Velocity (b) S-Wave velocity structure of Sedayu area

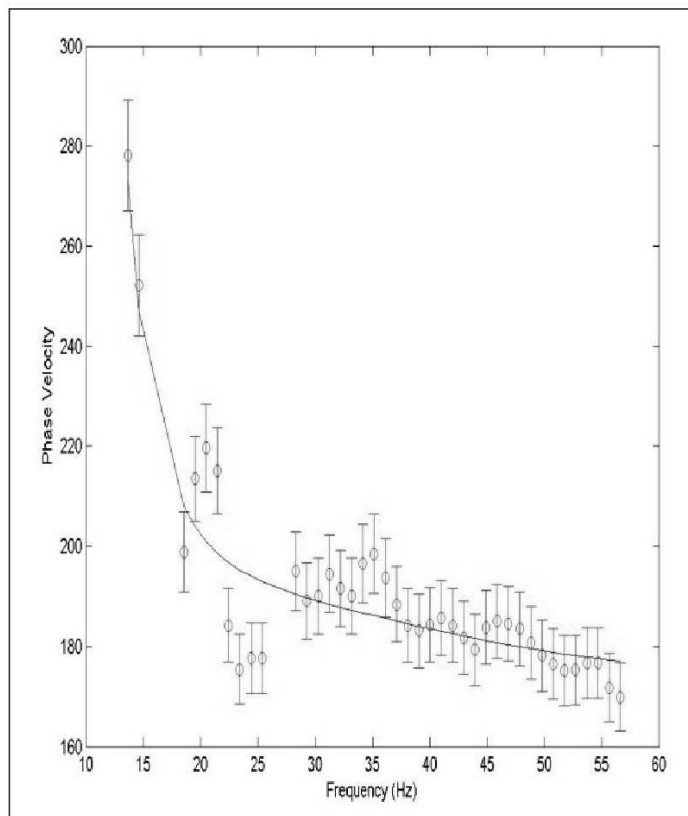

(a)

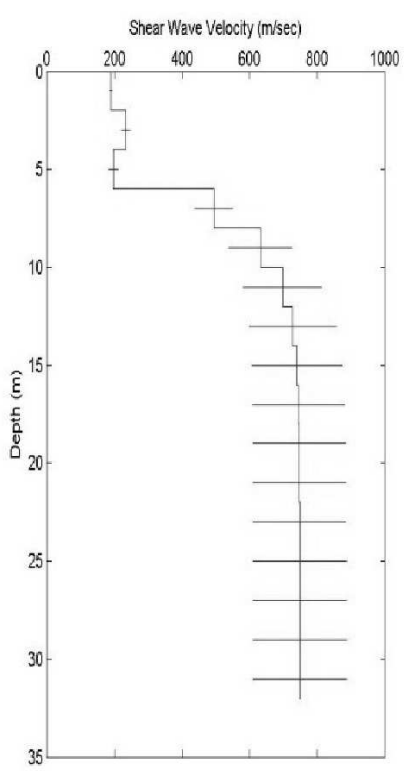

(b)

Figure 4f: (a) Phase Velocity (b) S-Wave velocity structure of Bantul area 


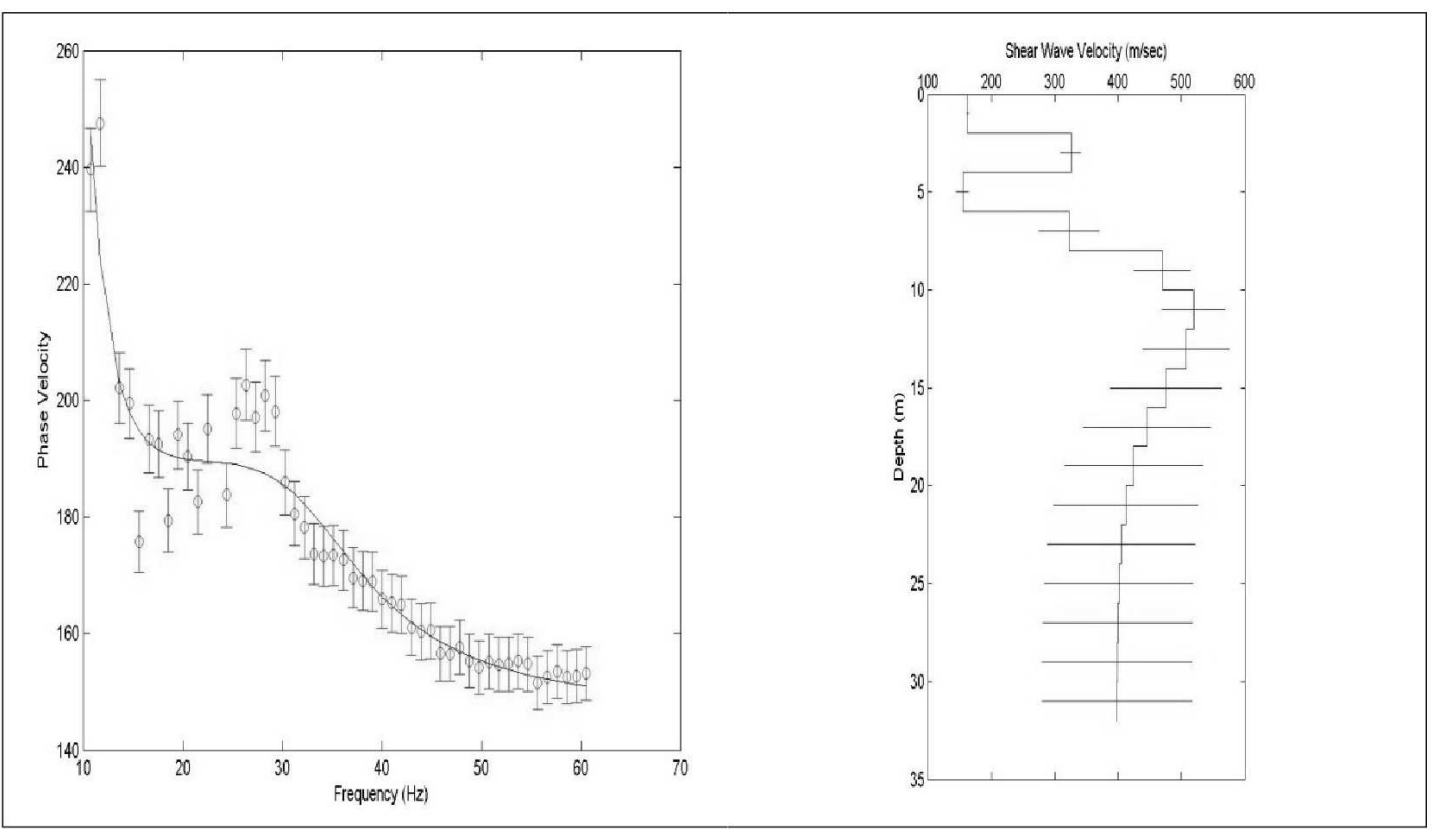

(a)

(b)

Figure 5a: (a) Phase Velocity (b) S-Wave velocity structure of Sanden area

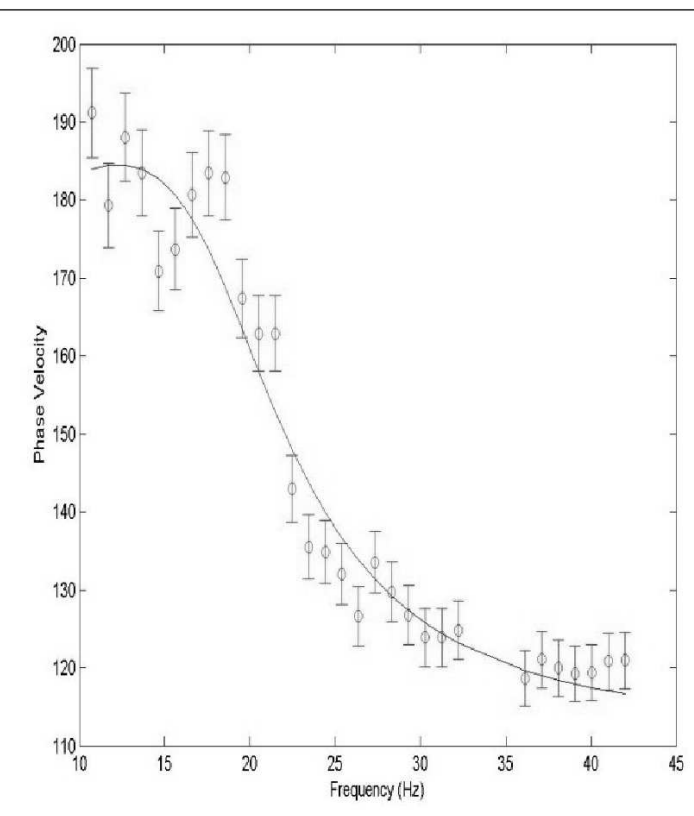

(a)

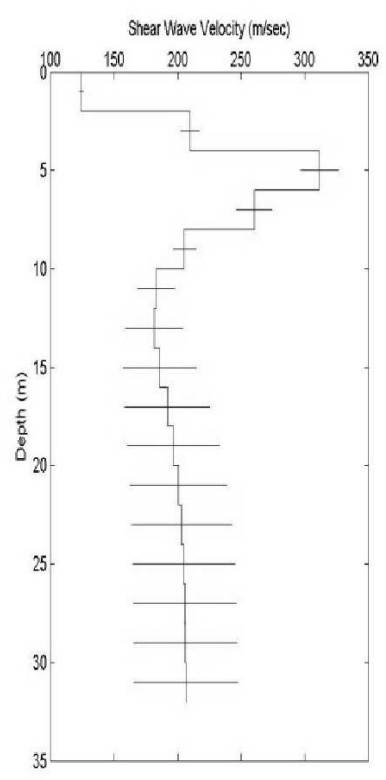

(b)

Figure 5b: (a) Phase Velocity (b) S-Wave velocity structure of Imogiri area 


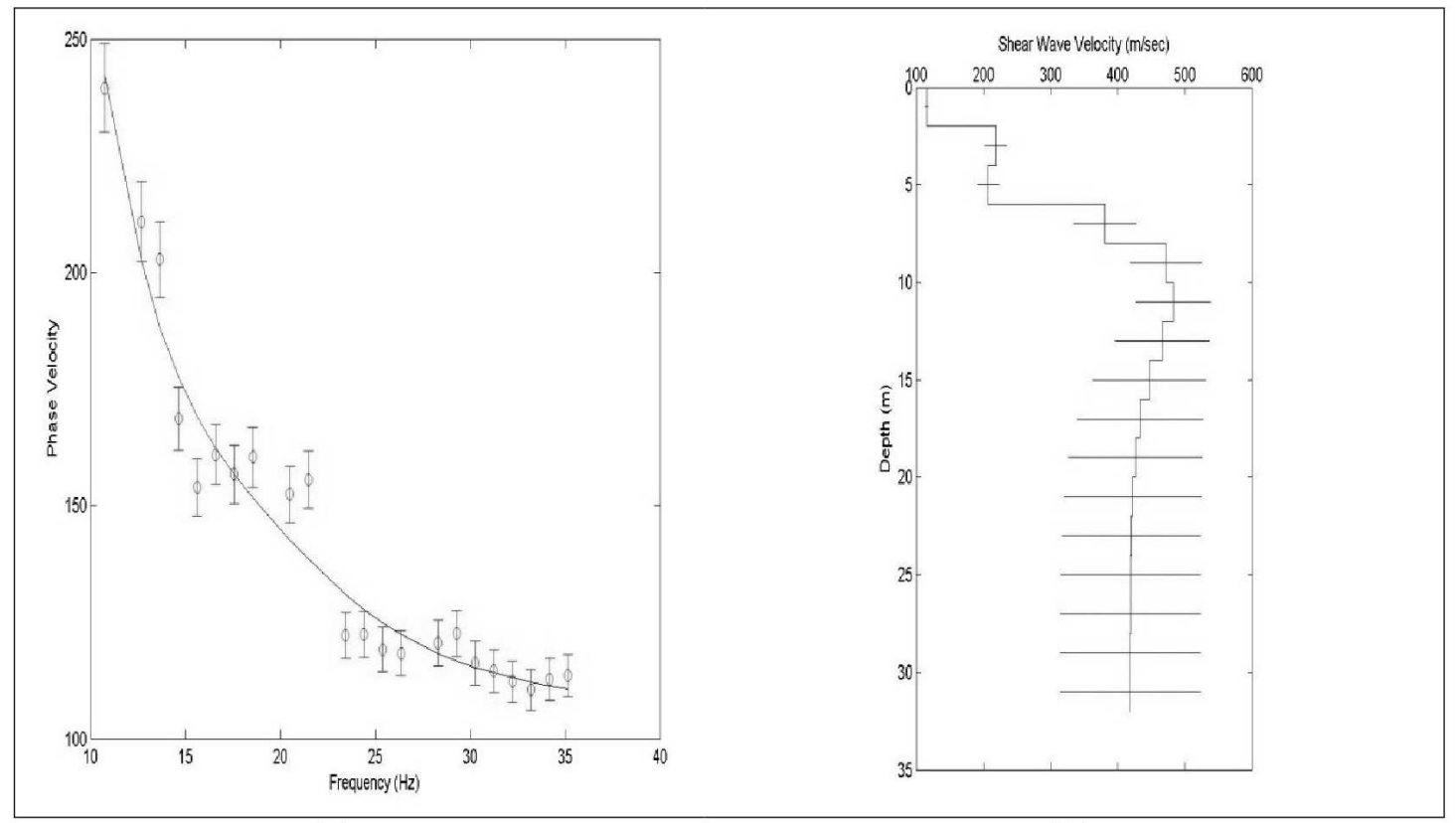

(a)

(b)

Figure 5c: (a) Phase Velocity (b) S-Wave velocity structure of Pajangan area

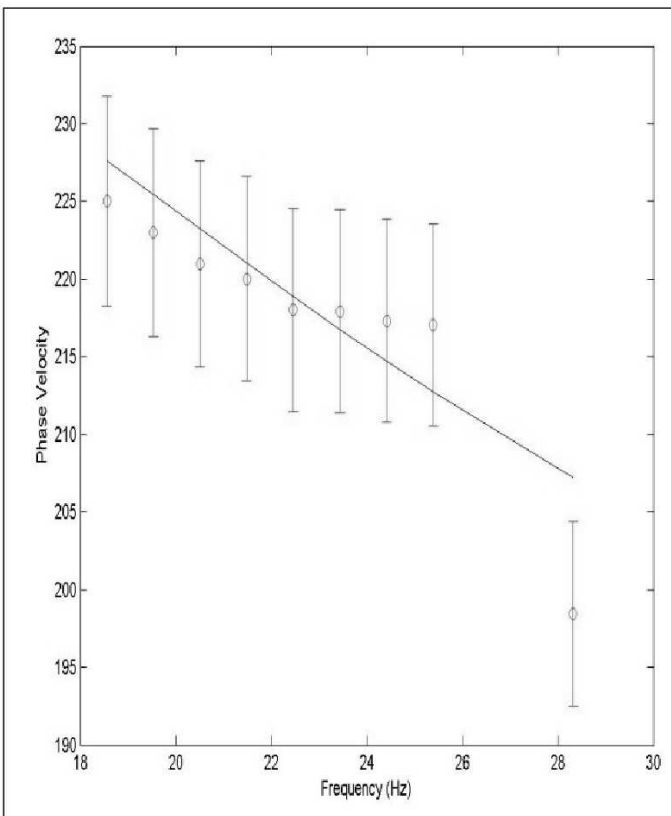

(a)

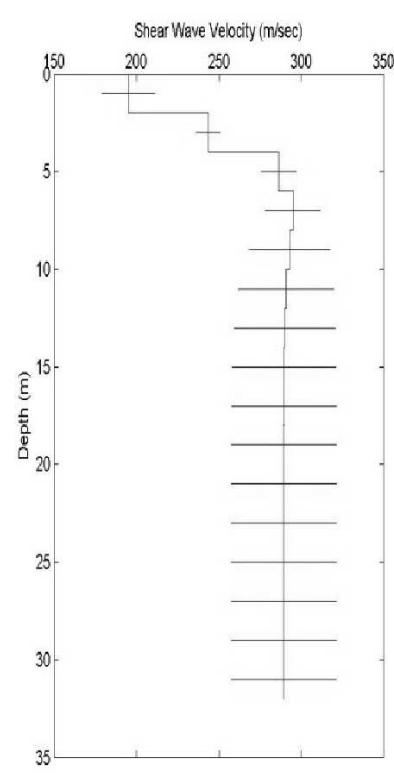

(b)

Figure 5d: (a) Phase Velocity (b) S-Wave velocity structure of Dlinggo area 


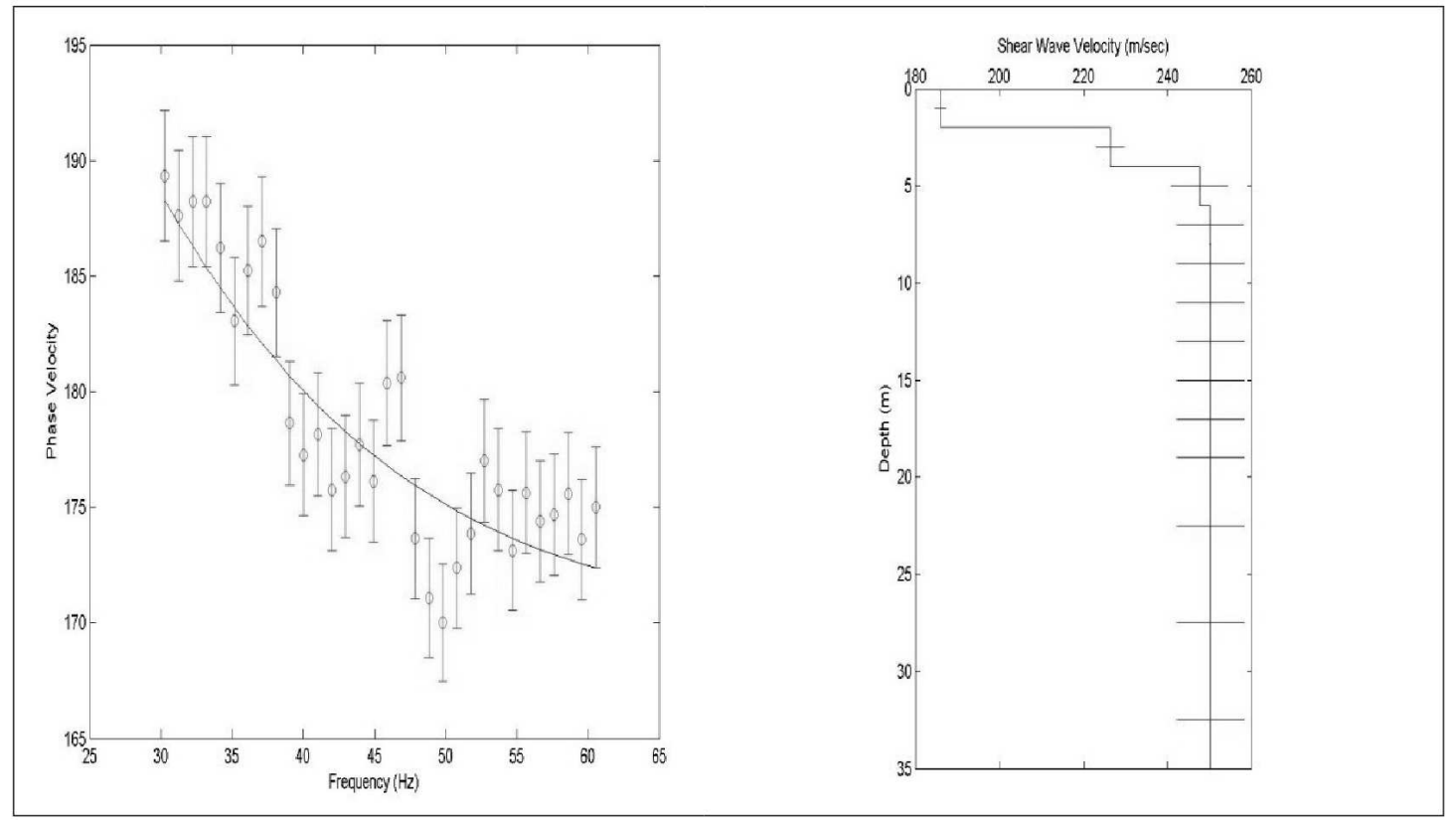

(a)

(b)

Figure 6a: (a) Phase Velocity (b) S-Wave velocity structure of Jetis area

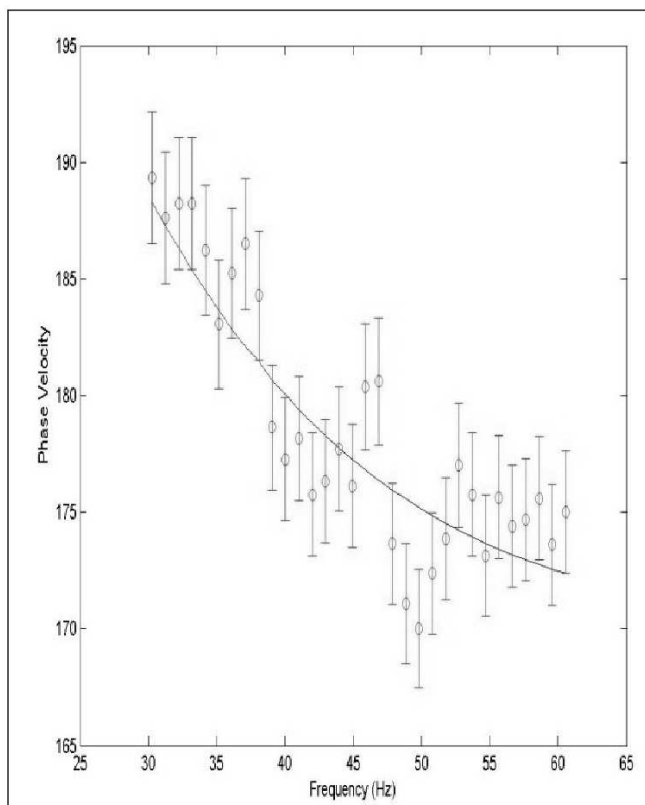

(a)

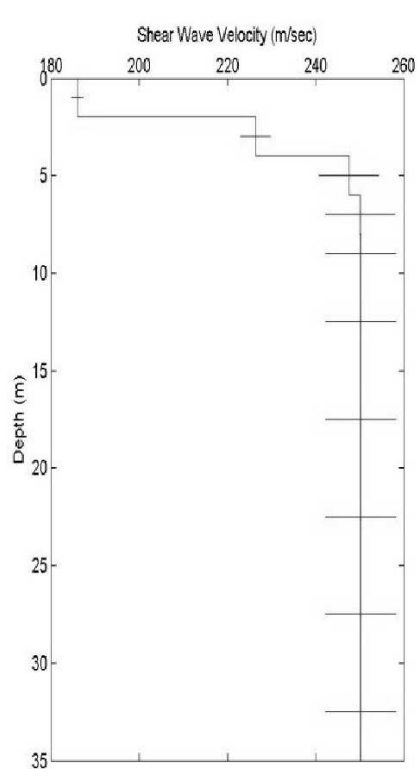

(b)

Figure 6b: (a) Phase Velocity (b) S-Wave velocity structure of Pleret area 


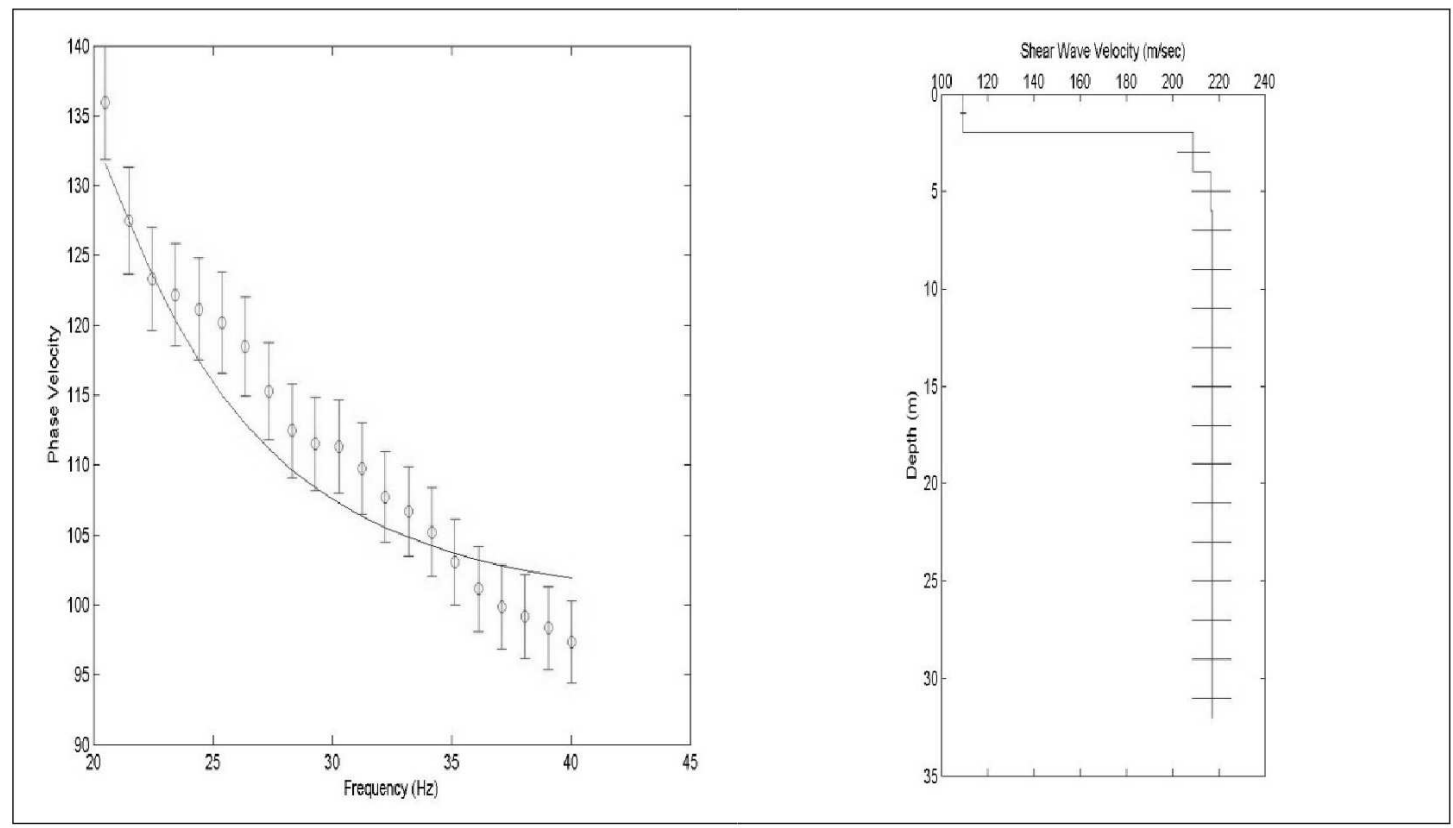

(a)

(b)

Figure 6c: (a) Phase Velocity (b) S-Wave velocity structure of Srandakan area

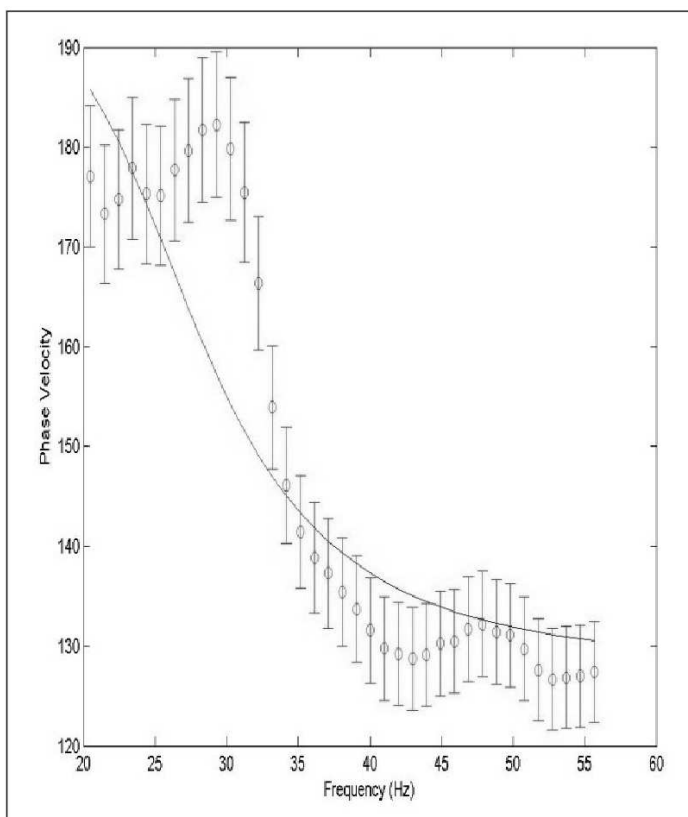

(a)

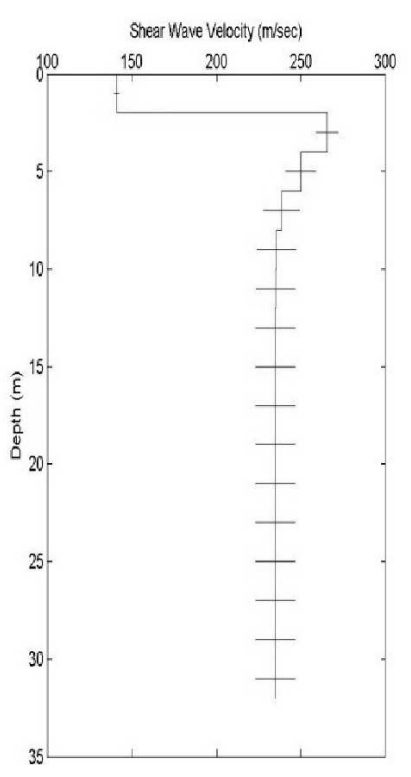

(b)

Figure7a: (a) Phase Velocity (b) S-Wave velocity structure of Kretek area 


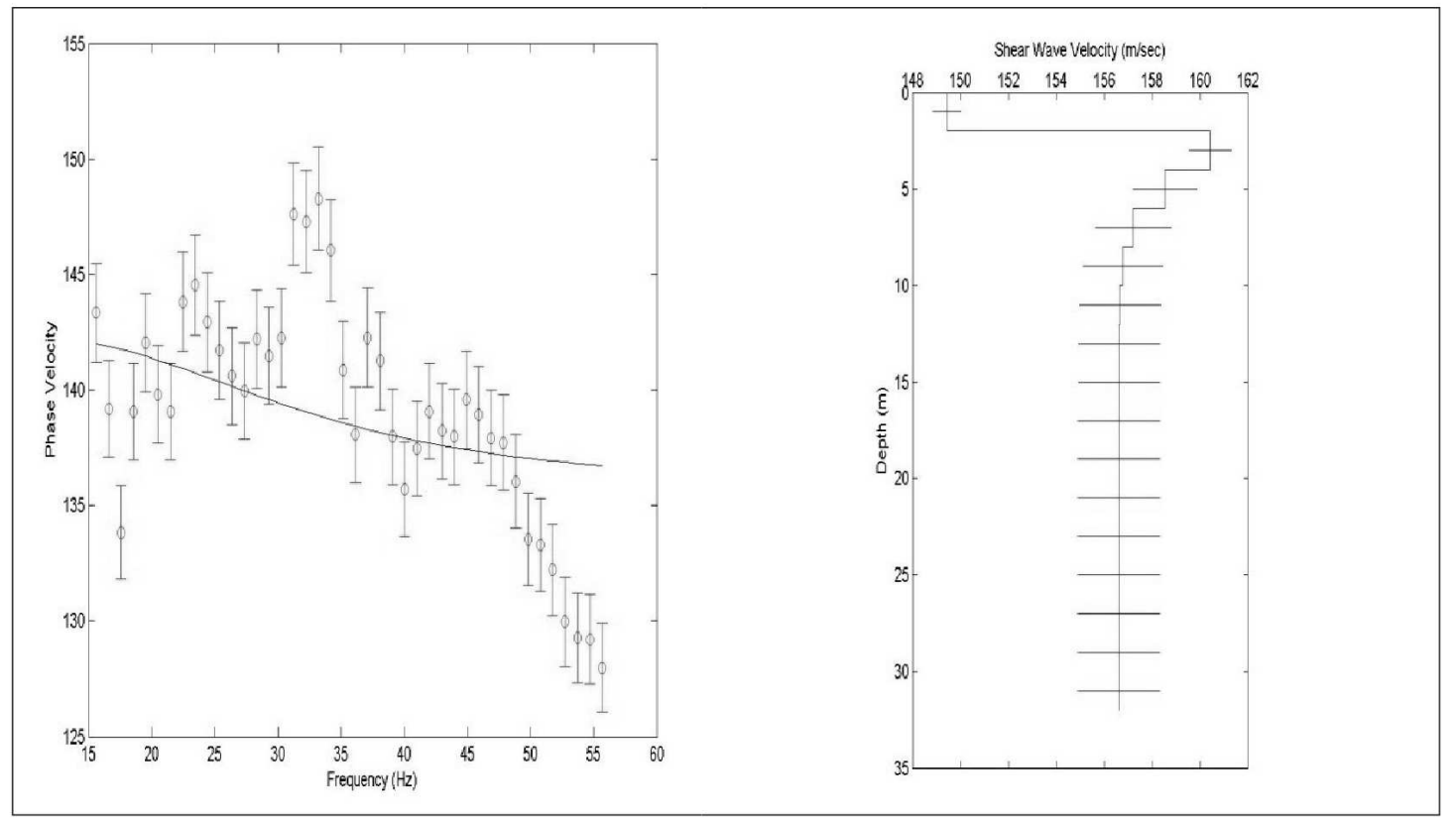

(a) (b)

Figure7b: (a) Phase Velocity (b) S-Wave velocity structure of Pundong area 
Table 1: Estimated shear wave velocities in Watu, Pudong, Bantul

\begin{tabular}{cccccccc}
\hline $\begin{array}{c}\text { Layer's } \\
\text { Thickness } \\
(\mathrm{m})\end{array}$ & $\begin{array}{c}\text { SPT } \\
(\mathrm{N})\end{array}$ & $\begin{array}{c}\boldsymbol{\gamma}_{\text {eff }} \\
\left(K N / \mathrm{m}^{3}\right)\end{array}$ & $\begin{array}{c}\overline{\boldsymbol{\sigma}_{v}} \\
\left(K N / \mathrm{m}^{2}\right)\end{array}$ & $\begin{array}{c}\overline{\boldsymbol{\sigma}}_{0} \\
\left(K N / \mathrm{m}^{2}\right)\end{array}$ & $\boldsymbol{e}$ & $\begin{array}{c}\boldsymbol{v}_{s} \\
\left(\mathrm{~ms}^{-1}\right)\end{array}$ & $\begin{array}{c}\boldsymbol{v}_{s} \\
\left(\mathrm{~ms}^{-1}\right)\end{array}$ \\
\hline 4 & 12 & 7.05 & 28.2 & 16.66 & 1.57 & 82.61 & 98.80 \\
7.5 & 11 & 6.53 & 77 & 44.53 & 1.49 & 103.40 & 133.53 \\
9 & 18 & 6.9 & 139 & 81.24 & 1.41 & 123.09 & 163.56 \\
1 & 17 & 5.7 & 144.7 & 88.93 & 1.41 & 135.20 & 167.3 \\
8.5 & 33 & 6.59 & 200.7 & 122.05 & 1.5 & 150.27 & 170.65 \\
5 & 32 & 6.56 & 233.7 & 139.94 & 1.54 & 154.46 & 171.79 \\
\hline
\end{tabular}

Table 2: Estimated shear wave velocities in Tempuran, near Opak River

\begin{tabular}{|c|c|c|c|c|c|c|c|}
\hline $\begin{array}{c}\text { Layer's } \\
\text { Thickness } \\
\text { (m) }\end{array}$ & $\begin{array}{r}\text { SPT } \\
(\mathrm{N})\end{array}$ & $\begin{array}{c}\mathcal{Y e f f} \\
\left(K N / m^{3}\right)\end{array}$ & $\begin{array}{c}\overline{\boldsymbol{\sigma}_{v}} \\
\left(K N / m^{2}\right)\end{array}$ & $\begin{array}{c}\overline{\sigma_{0}} \\
\left(K N / m^{2}\right)\end{array}$ & $e$ & $\begin{array}{c}v_{s} \\
\left(m s^{-1}\right)\end{array}$ & $\begin{array}{c}v_{s} \\
\left(m s^{-1}\right)\end{array}$ \\
\hline 1.7 & 17 & 6.81 & 11.58 & 7.91 & 1.49 & 74.68 & 86.69 \\
\hline 6.3 & 18 & 6.71 & 53.85 & 31.28 & 1.57 & 103.26 & 115.64 \\
\hline 4 & 17 & 7.24 & 82.85 & 48.58 & 1.49 & 107.3 & 136.47 \\
\hline 1 & 16 & 5.69 & 88.54 & 52.56 & 1.41 & 121.4 & 146.69 \\
\hline 13 & 33 & 6.59 & 174.21 & 105.94 & 1.5 & 146.07 & 164.72 \\
\hline
\end{tabular}

Table 3: Estimated shear wave velocities in Pranti, Pudong, Bantul

\begin{tabular}{cccccccc}
\hline $\begin{array}{c}\text { Layer's } \\
\text { Thickness } \\
(\mathrm{m})\end{array}$ & $\begin{array}{c}\text { SPT } \\
(\mathrm{N})\end{array}$ & $\begin{array}{c}\boldsymbol{\gamma}_{\text {eff }} \\
\left(K N / \mathrm{m}^{3}\right)\end{array}$ & $\begin{array}{c}\overline{\boldsymbol{\sigma}}_{v} \\
\left(K N / \mathrm{m}^{2}\right)\end{array}$ & $\begin{array}{c}\overline{\boldsymbol{\sigma}}_{0} \\
\left(K N / m^{2}\right)\end{array}$ & $\boldsymbol{e}$ & $\begin{array}{c}\boldsymbol{v}_{s} \\
\left(\mathrm{~ms}^{-1}\right)\end{array}$ & $\begin{array}{c}\boldsymbol{v}_{s} \\
\left(\mathrm{~ms}^{-1}\right)\end{array}$ \\
\hline 4.2 & 18 & 6.06 & 25.45 & 18.13 & 1.41 & 93.53 & 112.42 \\
4.5 & 16 & 6.94 & 56.68 & 32.97 & 1.57 & 100.54 & 117.18 \\
2 & 7 & 5.69 & 68.06 & 45.37 & 1.41 & 100.08 & 141.39 \\
4 & 18 & 6.45 & 93.86 & 55.24 & 1.41 & 117.70 & 148.52 \\
5.5 & 19 & 6.75 & 130.99 & 75.22 & 1.57 & 124.12 & 144.01 \\
8 & 16 & 6.65 & 184.19 & 109.73 & 1.49 & 130.01 & 167.30 \\
1.5 & 10 & 5.69 & 192.73 & 128.49 & 1.41 & 130.94 & 183.42 \\
9.5 & 33 & 6.59 & 255.34 & 155.28 & 1.5 & 157.67 & 181.24 \\
\hline
\end{tabular}

Table 4: Estimated shear wave velocities in BPKP1, J1 Parangtritis, Yogyakarta

\begin{tabular}{cccccccc}
\hline $\begin{array}{c}\text { Layer's } \\
\text { Thickness } \\
(\mathrm{m})\end{array}$ & $\begin{array}{c}\text { SPT } \\
(\mathrm{N})\end{array}$ & $\begin{array}{c}\boldsymbol{\gamma}_{\text {eff }} \\
\left(K N / \mathrm{m}^{3}\right)\end{array}$ & $\begin{array}{c}\overline{\boldsymbol{\sigma}}_{v} \\
\left(K N / \mathrm{m}^{2}\right)\end{array}$ & $\begin{array}{c}\overline{\boldsymbol{\sigma}}_{0} \\
\left(K N / m^{2}\right)\end{array}$ & $e$ & $\begin{array}{c}\boldsymbol{v}_{s} \\
\left(m s^{-1}\right)\end{array}$ & $\begin{array}{c}\boldsymbol{v}_{s} \\
\left(m s^{-1}\right)\end{array}$ \\
\hline 5.7 & 21 & 6.37 & 36.31 & 25.34 & 1.54 & 100.54 & 112.06 \\
5.3 & 14 & 5.99 & 68 & 44.67 & 1.57 & 109.72 & 126.42 \\
1.5 & 28 & 6.40 & 77.66 & 46.50 & 1.54 & 122.63 & 130.43 \\
10.5 & 22 & 6.49 & 146 & 86.65 & 1.57 & 132.62 & 149.20 \\
2.5 & 11 & 5.53 & 159.64 & 106.43 & 1.41 & 129.18 & 174.98 \\
4.5 & 43 & 6.56 & 189 & 113.17 & 1.54 & 155.66 & 162.91 \\
\hline
\end{tabular}


Table 5: Estimated shear wave velocities in BPKP2, Jl Parangtritis, Yogyakarta

\begin{tabular}{cccccccc}
\hline $\begin{array}{c}\text { Layer's } \\
\text { Thickness } \\
(\mathrm{m})\end{array}$ & $\begin{array}{c}\mathrm{SPT} \\
(\mathrm{N})\end{array}$ & $\begin{array}{c}\mathcal{\gamma}_{\text {eff }} \\
\left(K N / \mathrm{m}^{3}\right)\end{array}$ & $\begin{array}{c}\overline{\boldsymbol{\sigma}_{v}} \\
\left(K N / \mathrm{m}^{2}\right)\end{array}$ & $\begin{array}{c}\overline{\boldsymbol{\sigma}} \\
\left(K N / m^{2}\right)\end{array}$ & $\boldsymbol{e}$ & $\begin{array}{c}\boldsymbol{v}_{s} \\
\left(\mathrm{~ms}^{-1}\right)\end{array}$ & $\begin{array}{c}\boldsymbol{v}_{s} \\
\left(\mathrm{~ms}^{-1}\right)\end{array}$ \\
\hline 4 & 20 & 6.02 & 24 & 14.11 & 1.57 & 94.42 & 94.77 \\
3 & 29 & 6.83 & 44.49 & 26.41 & 1.54 & 106.83 & 113.23 \\
2 & 22 & 6.60 & 57.49 & 33.87 & 1.57 & 109.15 & 117.97 \\
1.5 & 37 & 6.56 & 67 & 40.12 & 1.54 & 123.31 & 125.70 \\
4.5 & 26 & 6.13 & 95 & 60.65 & 1.54 & 128.83 & 139.39 \\
2 & 8 & 6.34 & 107.6 & 67.67 & 1.41 & 106.29 & 156.25 \\
3 & 30 & 6.44 & 126.92 & 75.27 & 1.54 & 136.47 & 147.12 \\
\hline
\end{tabular}

Table 6: Estimated shear wave velocities in Karang Semut, Imogiri

\begin{tabular}{cccccccc}
\hline $\begin{array}{c}\text { Layer's } \\
\text { Thickness } \\
(\mathrm{m})\end{array}$ & $\begin{array}{c}\mathrm{SPT} \\
(\mathrm{N})\end{array}$ & $\begin{array}{c}\boldsymbol{\gamma}_{\text {eff }} \\
\left(K N / \mathrm{m}^{3}\right)\end{array}$ & $\begin{array}{c}\overline{\boldsymbol{\sigma}} \boldsymbol{v} \\
\left(K N / \mathrm{m}^{2}\right)\end{array}$ & $\begin{array}{c}\overline{\boldsymbol{\sigma}_{0}} \\
\left(K N / m^{2}\right)\end{array}$ & $e$ & $\begin{array}{c}\boldsymbol{v}_{s} \\
\left(\mathrm{~ms}^{-1}\right)\end{array}$ & $\begin{array}{c}\boldsymbol{v}_{s} \\
\left(\mathrm{~ms}^{-1}\right)\end{array}$ \\
\hline 4.5 & 17 & 6.57 & 29.57 & 17.10 & 1.49 & 91.67 & 105.11 \\
1.5 & 31 & 6.55 & 39 & 23.35 & 1.54 & 107.47 & 109.79 \\
1 & 21 & 6.37 & 45.77 & 26.62 & 1.57 & 105.31 & 111.08 \\
1 & 34 & 6.56 & 52.33 & 31.33 & 1.54 & 115.69 & 118.17 \\
3.5 & 24 & 6.83 & 76.24 & 44.71 & 1.54 & 115.22 & 129.16 \\
2 & 10 & 5.69 & 87.62 & 58.41 & 1.41 & 111.84 & 150.61 \\
6 & 40 & 6.57 & 127 & 76.05 & 1.54 & 152.48 & 147.50 \\
\hline
\end{tabular}

Table 7: Estimated shear wave velocities in Krajan, Ponkosari, Bantul

\begin{tabular}{cccccccc}
\hline $\begin{array}{c}\text { Layer's } \\
\text { Thickness } \\
(\mathrm{m})\end{array}$ & $\begin{array}{c}\text { SPT } \\
(\mathrm{N})\end{array}$ & $\begin{array}{c}\boldsymbol{\gamma}_{\text {eff }} \\
\left(K N / \mathrm{m}^{3}\right)\end{array}$ & $\begin{array}{c}\overline{\boldsymbol{\sigma}}_{v} \\
\left(K N / \mathrm{m}^{2}\right)\end{array}$ & $\begin{array}{c}\overline{\boldsymbol{\sigma}}_{0} \\
\left(K N / m^{2}\right)\end{array}$ & $\boldsymbol{e}$ & $\begin{array}{c}\boldsymbol{v}_{s} \\
\left(\mathrm{~ms}^{-1}\right)\end{array}$ & $\begin{array}{c}\boldsymbol{v}_{s} \\
\left(\mathrm{~ms}^{-1}\right)\end{array}$ \\
\hline 9 & 20 & 6.83 & 61.47 & 35.85 & 1.71 & 106.99 & 107.72 \\
2.5 & 17 & 6.69 & 78.2 & 47.09 & 1.62 & 110.34 & 123.52 \\
5.5 & 31 & 6.67 & 114.87 & 73.12 & 1.63 & 132.18 & 136.88 \\
10 & 24 & 6.72 & 182 & 108.79 & 1.64 & 138.23 & 150.05 \\
19 & 40 & 6.58 & 307 & 183.80 & 1.53 & 169.17 & 185.19 \\
\hline
\end{tabular}

Table 8: Estimated shear wave velocities in Bambang Lipuro, Bantul

\begin{tabular}{cccccccc}
\hline $\begin{array}{c}\text { Layer's } \\
\text { Thickness } \\
(\mathrm{m})\end{array}$ & $\begin{array}{c}\mathrm{SPT} \\
(\mathrm{N})\end{array}$ & $\begin{array}{c}\boldsymbol{\gamma}_{\text {eff }} \\
\left(K N / m^{3}\right)\end{array}$ & $\begin{array}{c}\overline{\boldsymbol{\sigma}_{v}} \\
\left(K N / m^{2}\right)\end{array}$ & $\begin{array}{c}\overline{\bar{\sigma}_{0}} \\
\left(K N / m^{2}\right)\end{array}$ & $\boldsymbol{e}$ & $\begin{array}{c}\boldsymbol{v}_{s} \\
\left(\mathrm{~ms}^{-1}\right)\end{array}$ & $\begin{array}{c}\boldsymbol{v}_{s} \\
\left(\mathrm{~ms}^{-1}\right)\end{array}$ \\
\hline 4 & 19 & 6.52 & 26 & 15.27 & 1.51 & 91.39 & 100.80 \\
2 & 15 & 6.44 & 38.88 & 23.13 & 1.45 & 95.74 & 116.42 \\
10 & 28 & 6.47 & 103.58 & 63.21 & 1.47 & 129.20 & 147.72 \\
2 & 22 & 6.27 & 116 & 77.33 & 1.36 & 128.86 & 166.72 \\
6.5 & 25 & 6.4 & 157.70 & 95.90 & 1.45 & 138.60 & 166.12 \\
1.5 & 13 & 6.30 & 167 & 109.66 & 1.35 & 126.44 & 183.07 \\
24 & 30 & 6.58 & 325 & 194.61 & 1.53 & 162.93 & 187.86 \\
\hline
\end{tabular}


Table 9: Estimated shear wave velocities in Wijirejo, Pandak, Bantul

\begin{tabular}{cccccccc}
\hline $\begin{array}{c}\text { Layer's } \\
\text { Thickness } \\
(\mathrm{m})\end{array}$ & $\begin{array}{c}\text { SPT } \\
(\mathrm{N})\end{array}$ & $\begin{array}{c}\boldsymbol{\gamma}_{\text {eff }} \\
\left(K N / m^{3}\right)\end{array}$ & $\begin{array}{c}\overline{\boldsymbol{\sigma}}_{v} \\
\left(K N / \mathrm{m}^{2}\right)\end{array}$ & $\begin{array}{c}\overline{\boldsymbol{\sigma}} \\
\left(K N / m^{2}\right)\end{array}$ & $e$ & $\begin{array}{c}v_{s} \\
\left(\mathrm{~ms}^{-1}\right)\end{array}$ & $\begin{array}{c}v_{s} \\
\left(\mathrm{~ms}^{-1}\right)\end{array}$ \\
\hline 8 & 17 & 6.47 & 51.76 & 31.43 & 1.47 & 103.32 & 124.04 \\
7 & 27 & 6.71 & 98.73 & 60.04 & 1.63 & 124.88 & 130.30 \\
1 & 10 & 5.81 & 104.54 & 67.69 & 1.36 & 114.66 & 161.27 \\
1.2 & 38 & 6.63 & 112.50 & 69.36 & 1.63 & 136.67 & 135.09 \\
1.8 & 12 & 6.27 & 123.79 & 76.57 & 1.36 & 117.76 & 166.31 \\
26 & 40 & 6.65 & 296.69 & 177.66 & 1.58 & 167.13 & 177.26 \\
\hline
\end{tabular}

Table 10: Soil Classification based on $v_{s}^{30}$ from SASW and SNI-1726-2002

\begin{tabular}{|l|c|c|c|}
\hline \multicolumn{1}{|c|}{ Area } & $\begin{array}{c}\text { Soft soil } \\
\bar{v}_{s}<175 \\
\left(m s^{-1}\right)\end{array}$ & $\begin{array}{c}\text { Medium Soil } \\
175 \leq \bar{v}_{s}<350 \\
\left(m s^{-1}\right)\end{array}$ & $\begin{array}{c}\text { Dense Soil } \\
\bar{v}_{s} \geq 350 \\
\left(m s^{-1}\right)\end{array}$ \\
\hline Bambang Lipuro & $\sqrt{ }$ & & \\
\hline Banguntapan & & $\sqrt{ }$ & \\
\hline B Sewon & & $\sqrt{ }$ & $\sqrt{ }$ \\
\hline Pundong & $\sqrt{ }$ & $\sqrt{ }$ \\
\hline Pajangan & & $\sqrt{ }$ & \\
\hline Piyungan & & $\sqrt{ }$ & \\
\hline Dlinggo & & $\sqrt{ }$ & \\
\hline Imogiri & & $\sqrt{ }$ & \\
\hline Kasihan & & $\sqrt{ }$ & \\
\hline Sedayu & & $\sqrt{ }$ & \\
\hline Bantul & & $\sqrt{ }$ & \\
\hline Jetis & & $\sqrt{ }$ & \\
\hline Kretek & & $\sqrt{ }$ & \\
\hline Pandak & & & \\
\hline Pleret & & & \\
\hline Sanden & & & \\
\hline Srandakan & & & \\
\hline
\end{tabular}


Table 11. Soil Classification based on $v_{s}^{30}$ from SPT and SNI-1726-2002

\begin{tabular}{|l|c|c|c|}
\hline \multicolumn{1}{|c|}{ Area } & $\begin{array}{c}\text { Soft soil } \\
\bar{v}_{s}<175 \\
\left(m s^{-1}\right)\end{array}$ & $\begin{array}{c}\text { Medium Soil } \\
175 \leq \bar{v}_{s}<350 \\
\left(m s^{-1}\right)\end{array}$ & $\begin{array}{c}\text { Dense Soil } \\
\bar{v}_{s} \geq 350 \\
\left(m s^{-1}\right)\end{array}$ \\
\hline Watu, Pudong, & $\sqrt{ }$ & & \\
\hline $\begin{array}{l}\text { Tempuran, Opak } \\
\text { River }\end{array}$ & $\sqrt{ }$ & & \\
\hline Pranti, Pudong & $\sqrt{ }$ & \\
\hline $\begin{array}{l}\text { BPKP1, Jl } \\
\text { Parangtritis, } \\
\text { Yogyakarta }\end{array}$ & $\sqrt{ }$ & & \\
\hline $\begin{array}{l}\text { BPKP2, Jl } \\
\text { Parangtritis, }\end{array}$ & $\sqrt{ }$ & & \\
\hline $\begin{array}{l}\text { Karang Semut, } \\
\text { Imogiri }\end{array}$ & $\sqrt{ }$ & & \\
\hline Krajan, Ponkosari & $\sqrt{ }$ & & \\
\hline $\begin{array}{l}\text { Bambang Lipuro, } \\
\text { Bantul }\end{array}$ & $\sqrt{ }$ & & \\
\hline Wijirejo, Pandak, & $\sqrt{ }$ & & \\
\hline
\end{tabular}

